\title{
Quandary surrounding COVID19 transmission
}

\author{
Amit Kalra ${ }^{1}$, Nelly Chawla ${ }^{2}$ \\ 'Division of Infectious Diseases, Indiana University, IN, USA; \\ ${ }^{2}$ Public Health, IN, USA
}

Address for Correspondence: Dr. Amit Kalra, 1633 N Capitol Ave., Ste 750, Indiana University, Indianapolis, IN 46202, USA.

E-mail: amkalra@iu.edu

\begin{tabular}{|l|}
\hline Access this article online \\
\hline Website: \\
www.intern-med.com \\
\hline DOI: \\
10.2478/jtim-2020-0041 \\
\hline Quick Response Code: \\
\hline
\end{tabular}

Serious acute respiratory virus syndrome coronavirus 2 (SARS-CoV-2), the causative agent of Coronavirus Disease 2019 (COVID-19), has caused massive casualties around the world. With nearly a million lives lost to the virus and billions more swept by its biological and socioeconomic impacts, the means by which preventive and interventive approaches to the virus are handled have become matters of global debate. One of the most significant arguments as of today concerns the means of transmission of SARS-Cov-2, which is still a matter of scientific and political discussion. With the recent retraction and then partial acknowledgement by the Centers for Disease Control and Prevention (CDC) that airborne transmission of SARSCov-2 is responsible for a large number of cases, it has become even more evident that a clear representation of information is needed. The dogma surrounding the spread of this novel coronavirus needs to be re-evaluated and all measures need to be taken to protect mankind from this deadly virus without further delay.

According to the World Health Organization (WHO), airborne transmission is defined as the 'spread of an infectious agent caused by the dissemination of droplet nuclei (aerosols) that remain infectious when suspended in air over long distances and time' (WHO, 2020). The difference between droplets and aerosols, besides droplets being large particles (more than $5 \mu \mathrm{m}$ in diameter) and aerosols being smaller (less than $5 \mu \mathrm{m}$ in diameter), is that droplets from a sneeze, cough or simple conversation can be propelled 3-6 feet, while aerosols can remain suspended in the air for several hours. $^{[1]}$
The ongoing debate regarding the means of transmission of COVID-19, along with its ongoing spread and increasing incidence may be an indication that precautionary measures should be more stringent. Despite all the efforts taken by hospital staff in donning and doffing PPE, regularly handwashing and wearing surgical masks, there are a disproportionate number of healthcare workers getting infected. Recent hotbeds of virus dissemination included choir practices at churches, family dinners at restaurants and other gatherings. In the month of June alone, over 1500 workers were infected in a German slaughterhouse after becoming exposed. ${ }^{[2]}$ These instances, coupled with the empirical evidence from outbreaks on cruise ships, make transmission of the virus through air plausible and likely. Ong et al. ${ }^{[3]}$ also emphasised the plausibility of airborne transmission after positive samples of SARS-CoV-2 were found in patient rooms from the air outlet exhaust fans. Enough evidence about the transmission route of SARS-CoV-2 via airborne microdroplets has been found, as microscopic droplets containing infectious viral RNA have been found in the air. ${ }^{[4]}$

According to Morawska et al. ${ }^{[5]}$ it is bewildering that with all the evidence available, we are still not able to label the virus as airborne and protect our healthcare providers with proper airborne infection control procedures and at the same time not able to guide the public about the correct route of transmission of SARS-CoV-2.

Mr. Editor, the medical community needs to take the initiative and redefine the means of transmission using evidence-based medicine to mitigate proper prevention and infection 
control measures to control the spread of this dreaded viral infection. We feel that SARS-CoV-2 should be labeled as airborne infection and healthcare professionals need to take adequate precautions accordingly.

\section{Conflict of Interest}

None declared.

\section{REFERENCES}

1. Jayaweera M, Perera H, Gunawardana B, Manatunge J. Transmission of COVID-19 virus by droplets and aerosols: A critical review on the unresolved dichotomy. Environ Res 2020; 188: 109819.
2. Moulson F. German region in new lockdown after slaughterhouse outbreak. June 23, 2020. https://www.kaaltv.com/health/germanyimposes-lockdown-on-slaughterhouse-outbreak-region/5768804/. Accessed on September 22, 2020.

3. Ong SWX, Tan YK, Chia PY, Lee TH, Ng OT, Wong MSY, et al. Air, Surface Environmental, and Personal Protective Equipment Contamination by Severe Acute Respiratory Syndrome Coronavirus 2 (SARS-CoV-2) From a Symptomatic Patient. JAMA 2020; 323: 1610-2.

4. Morawska L, Milton DK. It is Time to Address Airborne Transmission of COVID-19. Clin Infect Dis 2020; ciaa939.

5. Morawska L, Cao J. Airborne transmission of SARS-CoV-2: The world should face the reality. Environ Int 2020; 139: 105730.

How to cite this article: Kalra A, Chawla N. Quandary surrounding COVID19 transmission. J Transl Intern Med 2020; 8: 274-5. 